\title{
Spatiotemporal mapping of groundwater quality for irrigation using geostatistical analysis combined with a linear regression method
}

\author{
Najme Yazdanpanah ${ }^{1}$
}

Received: 12 December 2015/Accepted: 23 December 2015/Published online: 22 January 2016

(C) Springer International Publishing Switzerland 2016

\begin{abstract}
Spatiotemporal assessment of groundwater quality for irrigation is essential for agricultural management. This study was conducted to quantify the spatiotemporal changes of Kerman groundwater irrigation quality during 1999-2010 using geostatistical analysis combined with a new method established based on regression coefficient (RC). Result showed that among the main soluble ions, $\mathrm{Na}^{+}$and $\mathrm{Cl}^{-}$had the highest concentrations. Except $\mathrm{Ca}^{+2}$, the average concentration of all other soluble ions and also EC were higher than the maximum permissible levels for drinking, however, $\mathrm{Na}^{+}, \mathrm{SO}_{4}^{-2}$ and EC showed no limitations for agricultural irrigation. Based on the proposed $\mathrm{RC}$, soluble $\mathrm{Na}^{+}, \mathrm{Ca}^{+2}, \mathrm{Cl}^{-}$, total cations, total anions and EC have gradually increased over the years. Soluble $\mathrm{Cl}^{-}$with 0.18 meq $\mathrm{l}^{-1} \mathrm{y}^{-1}$ showed averagely the highest value of RC. Also, EC exhibited an increasing trend with an average value of $16.8 \mu \mathrm{S} \mathrm{cm}-1$ $\mathrm{y}^{-1}$. In contrast, $\mathrm{Mg}^{+2}, \mathrm{SO}_{4}^{-2}$ and $\mathrm{SAR}$ exhibited negative values of $\mathrm{RC}$, while the value for $\mathrm{HCO}_{3}{ }^{-}$was zero. Based on nugget-to-sill ratios, the groundwater variables had moderate to strong spatial structure. Finally, the spatiotemporal changes of groundwater salinity (EC) and sodicity (SAR) have been mainly controlled by $\mathrm{Na}^{+}$and $\mathrm{Cl}^{-}$.
\end{abstract}

Electronic supplementary material The online version of this article (doi:10.1007/s40808-015-0071-9) contains supplementary material, which is available to authorized users.

Najme Yazdanpanah

najmeyazdanpanah@yahoo.com

1 Department of Water Engineering, Kerman Branch, Islamic Azad University, P.O. Box: 7635131167, Kerman, Iran
Keywords Agriculture water - Irrigation water quality · Geostatistics $\cdot$ Kerman · Salinity

\section{Introduction}

Groundwater is the main source of water supply for agriculture, especially in arid and semi-arid regions (Neshat et al. 2014). Therefore, assessment of groundwater quality is considerably essential in agricultural land to facilitate groundwater planning and management (Holtz 2009; Hassanzadeh et al. 2011). The excessive exploitation of groundwater for irrigation (Yang et al. 2008), inefficient irrigation methods (Arslan 2012), irrigation with lowquality saline water (Yazdanpanah and Mahmoodabadi 2013) and uncontrolled utilization of fertilizers (Neshat et al. 2014) in agricultural lands in addition to groundwater contamination by domestic and industrial waste water (Hassanzadeh et al. 2011), have led to groundwater salinity and pollution problems. Furthermore, because of the health and economic impacts associated with groundwater contamination, the assessment of groundwater quality must be taken into consideration for sustainable groundwater protection (Hassanzadeh et al. 2011). In fact, groundwater has become the only water source in arid and semi-arid regions because of the limited availability of surface water (Yazdanpanah et al. 2011; Asadi et al. 2012; Neshat et al. 2014). Therefore, the prevention of groundwater salinity and contamination is essential for effective groundwater resource management (Guo et al. 2007).

Since, the cost of the installation and maintenance of a groundwater monitoring network is extremely high (Yang et al. 2008), geostatistical analysis provides very useful techniques for handling spatially distributed data (Nourzadeh et al. 2012; Moosavi and Sepaskhah 2012; 
Mousavifard et al. 2013). This approach has been applied for the interpolation and mapping of water level (Kumar 2007; Theodossiou and Latinopoulos 2007; Yang et al. 2008; Sun et al. 2009; Dash et al. 2010; Yimit et al. 2011) as well as water quality and pollution (Gaus et al. 2003; Ghosh et al. 2004; Demir et al. 2009; Delgado et al. 2010; Nas and Berktay 2010; Baalousha 2010; Mendes and Ribeiro 2010; Arslan 2012). Also, geostatistical analysis plays an important role in the management and sustainability of regional water resources (Demir et al. 2009; Baalousha 2010; Dash et al. 2010). In this context, geostatistical methods can be combined in a geographical information system (GIS) framework to map the spatial distribution of groundwater characteristics (Theodossiou and Latinopoulos 2007; Neshat et al. 2014). In addition, the investigation of both spatial and temporal changes of groundwater variables has been reported in the literature (Sun et al. 2009; Arslan 2012).

Kriging is a geostatistical interpolation technique, which includes a number of methods such as simple Kriging, ordinary Kriging, co-Kriging, stratified Kriging and nonlinear Kriging (Nazarizadeh et al. 2006; Yang et al. 2008; Zehtabian et al. 2010; Yimit et al. 2011). Gaus et al. (2003) used disjunctive Kriging to interpolate the probability and concentration of arsenic concentrations in groundwater of Bangladesh. Theodossiou and Latinopoulos (2007) evaluated groundwater observation networks using the Kriging methodology to interpolate groundwater levels in the Anthemountas basin of northern Greece. Kuisi et al. (2009) used Kriging methods to assess the spatial variability of groundwater nitrate and salinity in the Amman-Zarqa Basin. Zehtabian et al. (2010) provided spatial distribution maps for some groundwater cations and anions in Garmsar watershed of Iran. Yimit et al. (2011) applied ordinary Kriging to map groundwater levels and salinity in Xinjiang, northwest China. Groundwater quality zonation was performed by Maghami et al. (2011) in Abadeh township of Iran using different geostatistical methods and finally Kriging was found as the best method for mapping the quality of drinking water in the study area.

Kerman plain in southeast part of Iran has been faced with sever groundwater problems. In this area, groundwater is the main resource of agricultural and municipal water supply. However, water table has continuously lowered in upper-lands due to excessive pumping of groundwater during the last two to three decades, so that more than $16 \mathrm{~m}$ drawdown in the aquifer happened during recent 20 years (Rezaei 2013). Pistachio (Pistacia vera) is the main cultivation in the region (Yazdanpanah et al. 2013) and fertilizers have been extensively used. From another point of view, the entrance of domestic and municipal wastewaters into the groundwater of lower-lands where Kerman city has been established has led to water raising and aquifer contamination (Hasanpour et al. 2011). These concerns underlie the importance of investigating groundwater vulnerability in the Kerman plain. Therefore, the objectives of this study were (1) to determine the most appropriate Kriging model for mapping the groundwater quality for irrigation in Kerman plain, and (2) to investigate the spatial and temporal changes in some chemical groundwater variables from 1999 to 2010. For this purpose, a new approach was proposed to model the spatiotemporal variability of the groundwater irrigation quality and finally the rate of changes over the years was quantified.

\section{Materials and methods}

\section{Study area description}

This study was performed in Kerman plain located between $56^{\circ} 30^{\prime}-57^{\circ} 30^{\prime} \mathrm{E}$ and $29^{\circ} 50^{\prime}-30^{\circ} 30^{\prime} \mathrm{N}$ with an area of $5478 \mathrm{~km}^{2}$, in an arid to semi-arid region in southeast Iran (Fig. 1). The elevation varies from 1700 to $1950 \mathrm{~m}$ a.s.l., sloping from south and south east toward the central and north western parts of the plain with a similar direction for the groundwater level. Figure 2 shows groundwater levels of the plain for the last year i.e. 2010 and the position of Kerman city and other urban areas. A long-term mean precipitation of the area is $140 \mathrm{~mm}$ per annum, which mainly occurs in winter. During the recent 25 years, the maximum and minimum amounts of rainfall have been recorded for years 1992 (307.2 $\mathrm{mm} \mathrm{year}^{-1}$ ) and 1998 $\left(56.3 \mathrm{~mm}\right.$ year $\left.^{-1}\right)$. The average annual temperature for this region is $16.5^{\circ} \mathrm{C}$ and varies from 1.9 to $28.9{ }^{\circ} \mathrm{C}$. At the north central side of the plain, Kerman city is located on a fine grain bed rock with low permeability leading to water accumulation beneath the city. This city with an area of 15,000 ha is one of the largest cities in south east of Iran, with a population of more than 530,000 (The Planning and Management Organization of Kerman Province 2011). In Kerman a majority of houses have absorption wells, which are the main sewage disposal method (Hassanzadeh et al. 2011), resulting in the groundwater pollution by domestic waste water.

Kerman plain is mostly composed of Cretaceous limestone covered by Quaternary deposits i.e. alluvial, evaporative and Aeolian sediments (Hassanzadeh et al. 2011). In general, there are two major geological facieses in the region (Hasanpour et al. 2011). First, limestone and dolomite in the eastern part of Kerman plain, which are contributing to the aquifer's recharge and second, marl facieses in the western part, which are consisting of evaporative sediments and leading to the groundwater salinity. According to the excavation of discovery wells and seismic studies (Aminizadeh et al. 2012), the thickness of the 
Fig. 1 The location of Kerman plain on Iran map
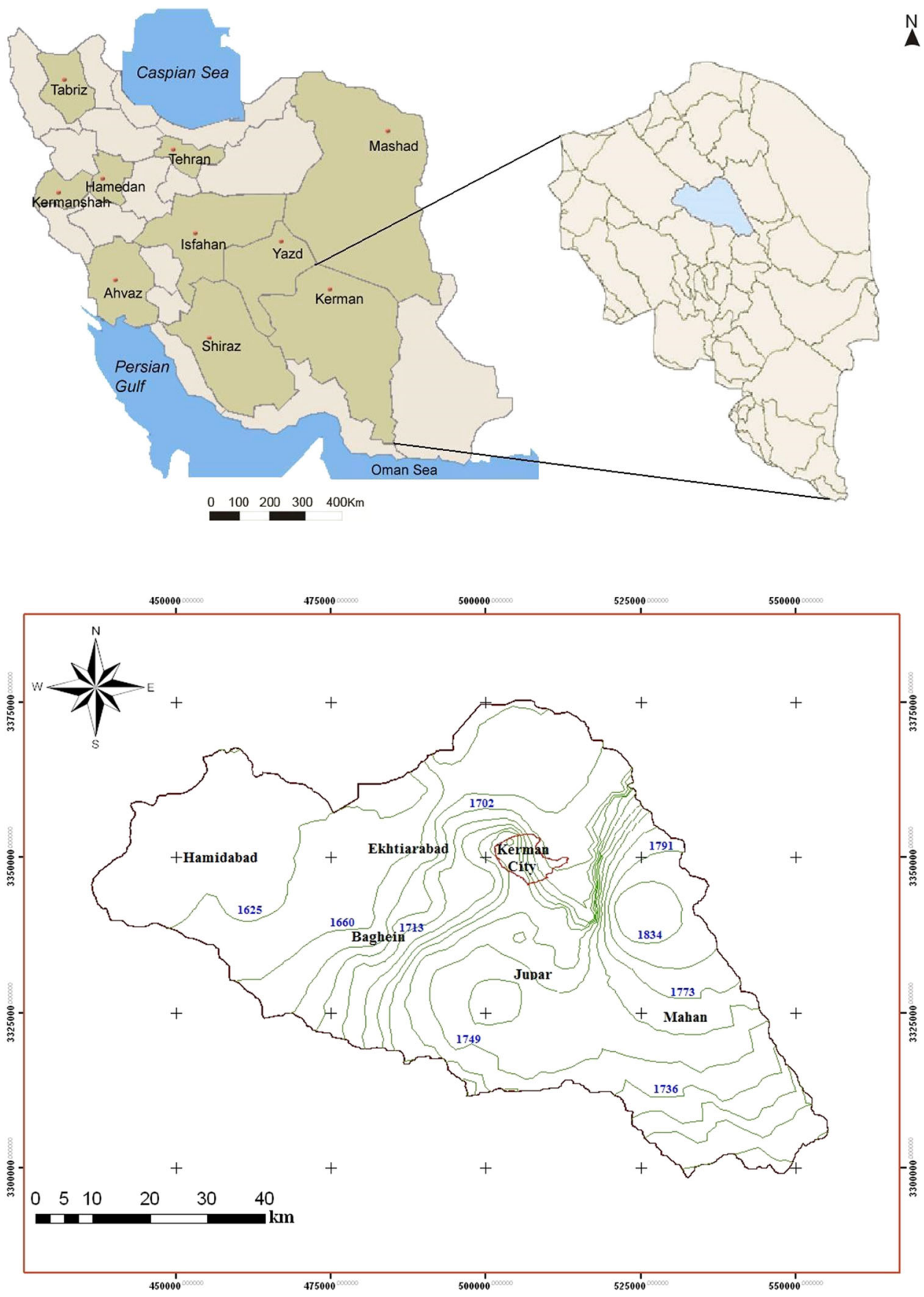

Fig. 2 Groundwater levels of Kerman aquifer for year 2010 and the position of Kerman city and other urban areas sediments is varied from 30 to $350 \mathrm{~m}$. The depth of the bed rock in south east and central parts of the plain is about $250 \mathrm{~m}$, whereas, in other regions it varied between 130 and $150 \mathrm{~m}$. Also, there is a deep basin underground in the west part of Kerman city.

\section{Database preparation}

In this study, groundwater quality data of 56 agricultural wells were collected from the Water Organization of
Kerman. For each well, the concentrations of main soluble ions including sodium $\left(\mathrm{Na}^{+}\right)$, calcium $\left(\mathrm{Ca}^{+2}\right)$, magnesium $\left(\mathrm{Mg}^{+2}\right)$, total cations, chloride $\left(\mathrm{Cl}^{-}\right)$, bicarbonate $\left(\mathrm{HCO}_{3}{ }^{-}\right)$, sulfate $\left(\mathrm{SO}_{4}^{-2}\right)$, total anions, and the values of electrical conductivity (EC) as well as sodium adsorption ratio (SAR) were obtained for years 1999-2010. Summary statistics for each groundwater variable were generated and then, a normality (Kolmogorov-Smirnov) test was conducted to assess the normal distribution of each one. Accordingly, the database was prepared using the obtained 
data for each groundwater variable. The value of each groundwater variable was compared with the maximum permissible levels for drinking and agriculture based on Environmental Protection Organization of Iran (2001) and the United States Environmental Protection Agency (2012).

To quantify the temporal changes of the selected groundwater variables over the studied period of years, a new approach was proposed. This method is established based on the regression coefficient concept. A regression equation can be used to predict the values of one variable knowing those of one or more others. In general, when a regression line is considered as linear (i.e. $y=a x+b$ ), the regression coefficient is a constant (a), which represents the rate of change of each groundwater variable (y) as a function of time (x); it is the slope of the regression line (Webster 1997). Therefore, the values of each groundwater variable against the corresponding years (from 1999 to 2010) were plotted and the best linear trend line was fitted. Then, the regression coefficient (a) was determined as a constant value for each groundwater variable, hereafter called "RC". Negative value of RC for each groundwater variable implies that the variable over time (years) has been reduced and vice versa.

\section{Geostatistical analysis}

Geostatistical analysis of data was performed in two stages including (1) the structural analysis, which aims at describing and modeling the spatial structure of the RC parameter for the groundwater variables, using a structural tool i.e. variogram; (2) the use of this structure for a given evaluation problem (e.g. to make up the maps of each groundwater RC parameter). In this study, some geostatistical algorithms including ordinary, simple, universal, indicator, probability, and disjunctive Kriging were tested (ESRI 2008). Through the analysis of the semi-variogram, the best model (e.g., spherical, exponential, or Gaussian) and the relevant parameters (nugget, sill, and range) were determined. According to variography analysis, spatiotemporal groundwater quality maps were derived for each variable.

According to the theoretical basis (ESRI 2008), the main tool in geostatistics is variogram, which expresses the spatial dependence between neighboring observations. The variogram, $\gamma \mathrm{h}$, can be defined as one-half the variance of the difference between attribute values at all points separated by $\mathrm{h}$ as (Li and Heap 2008):

$\gamma_{h}=\frac{1}{2 n} \sum_{i=1}^{n}\left[Z\left(x_{i}\right)-Z\left(x_{i}+h\right)\right]^{2}$

where $\gamma_{\mathrm{h}}$ is the semi-variance value for all pairs at a lag distance $\mathrm{h} ; \mathrm{Z}\left(\mathrm{x}_{\mathrm{i}}\right)$ is the regression coefficient (RC) of the selected groundwater variable at point $\mathrm{i} ; \mathrm{Z}\left(\mathrm{x}_{\mathrm{i}}+\mathrm{h}\right)$ is the $\mathrm{RC}$ value of the groundwater variable for other points separated from xi by a discrete distance $\mathrm{h}$; $\mathrm{xi}$ is the georeferenced position where the $\mathrm{Z}\left(\mathrm{x}_{\mathrm{i}}\right)$ value is measured; $\mathrm{n}$ represents the number of pairs of observations separated by the distance $h$.

\section{Model validation}

Prediction performances of the interpolation models were assessed by cross-validation. Basically, the input data were split into two subsets. The first subset of the available data was used to develop a model for prediction. The predicted values were then compared with the known values at the remaining locations using the validation tool. The effectiveness of subsequent interpolation efforts was evaluated based on relative root mean square error (RMSE) and also using mean absolute error (MAE) and mean bias error (MBE) parameters (Park and Vlek 2002):

RMSE $=\sqrt{\frac{\sum_{i=1}^{n}\left[Z \times\left(x_{i}\right)-Z\left(x_{i}\right)\right]^{2}}{n}}$

$\mathrm{MAE}=\frac{\sum_{i=1}^{n}\left|Z \times\left(x_{i}\right)-Z\left(x_{i}\right)\right|}{n}$

$\mathrm{MBE}=\frac{\sum_{i=1}^{n}\left[Z \times\left(x_{i}\right)-Z\left(x_{i}\right)\right]}{n}$

where $\mathrm{Z} \times\left(\mathrm{x}_{\mathrm{i}}\right)$ is the predicted value at point $\mathrm{xi}, \mathrm{Z}\left(\mathrm{x}_{\mathrm{i}}\right)$ is the observed value at point $x i$, and $n$ is the number of observations. Smaller values of the RMSE, MAE and MBE indicate that the estimated values are closer to the observed values. By this procedure, the best predictive model was selected to create spatiotemporal distribution maps for each groundwater variable.

\section{Results and discussion}

\section{Descriptive statistics}

Table 1 shows the amounts of groundwater variables of Kerman plain in comparison with the maximum permissible levels for drinking and agriculture irrigation. Among the studied cations and anions, soluble $\mathrm{Na}^{+}$with an average of $15.94 \mathrm{meq}{ }^{-1}$ and $\mathrm{Cl}^{-}$with an average of $14.53 \mathrm{meq}^{-1}$ showed the highest concentrations in the groundwater. As is clear, the average concentrations of $\mathrm{Na}^{+}$and $\mathrm{SO}_{4}^{-2}$ in addition to the amount of EC were higher than the maximum permissible levels for drinking, 
Table 1 Summary statistics of groundwater quality variables for Kerman plain aquifer based on 56 observation wells in comparison with the maximum permissible levels for drinking and agriculture

\begin{tabular}{|c|c|c|c|c|c|c|}
\hline Variable & Average & Minimum & Maximum & $\begin{array}{l}\text { Standard } \\
\text { deviation }\end{array}$ & $\begin{array}{l}\text { Max permissible level } \\
\text { for drinking }\end{array}$ & $\begin{array}{l}\text { Max permissible level } \\
\text { for agriculture }\end{array}$ \\
\hline $\mathrm{Na}^{+}\left(\right.$meq $\left.1^{-1}\right)$ & 15.94 & 0.84 & 113.29 & 19.87 & 7.61 & 39.13 \\
\hline $\mathrm{Ca}^{+2}\left(\right.$ meq $\left.1^{-1}\right)$ & 4.72 & 1.18 & 17.46 & 3.27 & 5.00 & 10.00 \\
\hline $\mathrm{Mg}^{+2}\left(\operatorname{meq~} 1^{-1}\right)$ & 6.48 & 1.24 & 28.83 & 5.39 & 6.17 & 2.47 \\
\hline Cations (meq $1^{-1}$ ) & 27.13 & 4.06 & 159.57 & 27.20 & - & - \\
\hline $\mathrm{Cl}^{-}\left(\right.$meq $\left.1^{-1}\right)$ & 14.53 & 0.46 & 112.43 & 18.85 & 7.04 & 14.08 \\
\hline $\mathrm{HCO}_{3}{ }^{-}\left(\right.$meq $\left.1^{-1}\right)$ & 4.19 & 1.76 & 11.83 & 1.90 & - & 9.84 \\
\hline $\mathrm{SO}_{4}^{-2}\left(\right.$ meq $\left.1^{-1}\right)$ & 8.38 & 0.81 & 41.34 & 8.49 & 2.60 & 9.90 \\
\hline Anions (meq $1^{-1}$ ) & 27.10 & 4.06 & 159.00 & 27.10 & - & - \\
\hline $\mathrm{EC}\left(\mu \mathrm{S} \mathrm{cm} \mathrm{c}^{-1}\right)$ & 2468.0 & 382.3 & 13792.9 & 2356.91 & 2000 & 2700 \\
\hline $\operatorname{SAR}\left(\operatorname{meq} 1^{-1}\right)^{0.5}$ & 5.99 & 0.65 & 23.60 & 4.85 & - & - \\
\hline
\end{tabular}

The maximum permissible levels are presented based on Environmental Protection Organization of Iran (2001) and the United States Environmental Protection Agency (2012). For equivalence and comparison, the unit of permissible values was converted from mg $1^{-1}$ to meq $1^{-1}$

Table 2 Area distribution of soluble cations within different classes in groundwater of Kerman plain

\begin{tabular}{|c|c|c|c|c|c|c|c|c|c|c|c|}
\hline \multicolumn{3}{|c|}{$\mathrm{Na}^{+}\left(\right.$meq $\left.1^{-1}\right)$} & \multicolumn{3}{|c|}{$\mathrm{Ca}^{+2}\left(\right.$ meq $\left.1^{-1}\right)$} & \multicolumn{3}{|c|}{$\mathrm{Mg}^{+2}\left(\right.$ meq $\left.\mathrm{I}^{-1}\right)$} & \multicolumn{3}{|c|}{ Total Cations (meq $1^{-1}$ ) } \\
\hline Class & $\begin{array}{l}\text { Area } \\
\left(\mathrm{km}^{2}\right)\end{array}$ & $\begin{array}{l}\text { Area } \\
(\%)\end{array}$ & Class & $\begin{array}{l}\text { Area } \\
\left(\mathrm{km}^{2}\right)\end{array}$ & $\begin{array}{l}\text { Area } \\
(\%)\end{array}$ & Class & $\begin{array}{l}\text { Area } \\
\left(\mathrm{km}^{2}\right)\end{array}$ & $\begin{array}{l}\text { Area } \\
(\%)\end{array}$ & Class & $\begin{array}{l}\text { Area } \\
\left(\mathrm{km}^{2}\right)\end{array}$ & $\begin{array}{l}\text { Area } \\
(\%)\end{array}$ \\
\hline $0.8-3.3$ & 85.54 & 1.56 & $1.2-1.7$ & 0 & 0.00 & $1.2-2.1$ & 19.36 & 0.35 & $4.1-8.2$ & 48.32 & 0.88 \\
\hline $3.3-4.6$ & 296.96 & 5.42 & $1.7-2.1$ & 40.00 & 0.73 & $2.1-2.6$ & 44.37 & 0.81 & $8.2-10.7$ & 133.57 & 2.44 \\
\hline $4.6-5.4$ & 250.49 & 4.57 & $2.1-2.6$ & 121.09 & 2.21 & $2.6-2.9$ & 44.50 & 0.81 & $10.7-12.2$ & 108.59 & 1.98 \\
\hline $5.4-6.7$ & 388.09 & 7.08 & $2.6-3.3$ & 547.16 & 9.99 & $2.9-3.4$ & 91.12 & 1.66 & $12.2-14.6$ & 266.14 & 4.86 \\
\hline $6.7-9.2$ & 634.33 & 11.58 & $3.3-4.3$ & 999.83 & 18.25 & $3.4-4.3$ & 222.77 & 4.07 & $14.6-18.9$ & 521.07 & 9.51 \\
\hline $9.2-13.7$ & 950.34 & 17.35 & $4.3-5.6$ & 2466.99 & 45.03 & $4.3-5.7$ & 780.09 & 14.24 & $18.9-26.1$ & 934.93 & 17.07 \\
\hline $13.7-21.8$ & 1444.76 & 26.37 & $5.6-7.4$ & 1030.94 & 18.82 & $5.7-8.1$ & 3796.52 & 69.30 & $26.1-38.6$ & 2862.29 & 52.25 \\
\hline $21.8-36.7$ & 1126.90 & 20.57 & $7.4-9.8$ & 216.18 & 3.95 & $8.1-11.9$ & 383.18 & 6.99 & $38.6-60.1$ & 489.04 & 8.93 \\
\hline $36.7-63.8$ & 300.65 & 5.49 & $9.8-13.1$ & 55.87 & 1.02 & $11.9-18.3$ & 96.15 & 1.76 & $60.1-96.6$ & 114.11 & 2.08 \\
\hline$>63.8$ & 0 & 0.00 & $>13.1$ & 0 & 0.00 & $>18.3$ & 0 & 0.00 & $>96.6$ & 0 & 0.00 \\
\hline
\end{tabular}

however they showed no limitation for agricultural water usage. On average, $\mathrm{Ca}^{+2}$ had lower concentration than the maximum permissible values for drinking and agriculture, whereas, the average concentrations of $\mathrm{Mg}^{+2}$ and $\mathrm{Cl}^{-}$were greater than the maximum permissible values. This means that among the studied variables, only the concentration of $\mathrm{Ca}^{+2}$ was less than permissible levels, whereas the other ones showed critical values particularly for drinking water usage. Dash et al. (2010) in studying groundwater quality parameters in Delhi found that $\mathrm{Cl}^{-}$levels in $62 \%$ and EC values in $69 \%$ of the area exceeded the permissible thresholds. The result of Hassanzadeh et al. (2011) indicated that the concentration of some major ions including $\mathrm{Na}^{+}, \mathrm{Ca}^{+2}, \mathrm{Mg}^{+2}, \mathrm{~K}^{+}, \mathrm{Cl}^{-}, \mathrm{SO} 4^{-2}$ and $\mathrm{EC}$ in groundwater of an urban area exceeded the maximum permissible level for drinking water, which was ascribed to enrichment beneath the city. The groundwater EC value is ranging from 382.3 to $13792.9 \mu \mathrm{S} \mathrm{cm}^{-1}$. The large variation in EC is mainly attributed to geochemical processes prevailing in this region (Pazand and Javanshir 2014).

Tables 2, 3 and 4 show the distribution of soluble cations, anions as well as EC and SAR within different classes in groundwater of Kerman aquifer. Overall, $75.87 \%$ of the area had $\mathrm{Na}^{+}$values in the range of 6.7-36.7 meq $1^{-1}, 82.1 \%$ of the aquifer showed $\mathrm{Ca}^{+2}$ concentrations ranging from 3.3 to $7.4 \mathrm{meq} \mathrm{l}^{-1}$ and $83.54 \%$ of the area had $\mathrm{Mg}^{+2}$ values in the range of 4.3-8.1 meq $\mathrm{l}^{-1}$. Also, the dominate class of $\mathrm{Cl}^{-}$was 6.3-36.2 meq $\mathrm{l}^{-1}$ (85.82\% of the area), $68.04 \%$ of the region had $\mathrm{HCO}_{3}{ }^{-}$values ranging from 3.6 to 5.2 meq $1^{-1}$, and $67.83 \%$ of the study area showed $\mathrm{SO}_{4}^{-2}$ values varying from 6.9 to $13.2 \mathrm{meq}^{-1}$. Furthermore, $81.90 \%$ of the study area had EC values higher than $1769 \mu \mathrm{S} \mathrm{cm}{ }^{-1}$, whereas the most dominant SAR values $(68.30 \%)$ were 
Table 3 Area distribution of soluble anions within different classes in groundwater of Kerman plain

\begin{tabular}{|c|c|c|c|c|c|c|c|c|c|c|c|}
\hline \multicolumn{3}{|c|}{$\mathrm{Cl}^{-}\left(\right.$meq $\left.1^{-1}\right)$} & \multicolumn{3}{|c|}{$\mathrm{HCO}_{3}{ }^{-}\left(\mathrm{meq} 1^{-1}\right)$} & \multicolumn{3}{|c|}{$\mathrm{SO}_{4}^{-2}\left(\right.$ meq $\left.1^{-1}\right)$} & \multicolumn{3}{|c|}{ Total Anions (meq $1^{-1}$ ) } \\
\hline Class & $\begin{array}{l}\text { Area } \\
\left(\mathrm{km}^{2}\right)\end{array}$ & $\begin{array}{l}\text { Area } \\
(\%)\end{array}$ & Class & $\begin{array}{l}\text { Area } \\
\left(\mathrm{km}^{2}\right)\end{array}$ & $\begin{array}{l}\text { Area } \\
(\%)\end{array}$ & Class & $\begin{array}{l}\text { Area } \\
\left(\mathrm{km}^{2}\right)\end{array}$ & $\begin{array}{l}\text { Area } \\
(\%)\end{array}$ & Class & $\begin{array}{l}\text { Area } \\
\left(\mathrm{km}^{2}\right)\end{array}$ & $\begin{array}{l}\text { Area } \\
(\%)\end{array}$ \\
\hline $0.4-2.9$ & 39.81 & 0.73 & $1.7-2.5$ & 153.76 & 2.81 & $0.8-2.4$ & 0 & 0.00 & $4.1-7.9$ & 29.79 & 0.54 \\
\hline $2.9-4.2$ & 156.86 & 2.86 & $2.5-3.1$ & 411.72 & 7.52 & $2.4-3.5$ & 232.44 & 4.24 & $7.9-10.2$ & 93.19 & 1.70 \\
\hline $4.2-4.9$ & 110.35 & 2.01 & $3.1-3.4$ & 298.02 & 5.44 & $3.5-4.2$ & 234.93 & 4.29 & $10.2-11.5$ & 60.22 & 1.10 \\
\hline $4.9-6.3$ & 325.41 & 5.94 & $3.4-3.6$ & 239.53 & 4.37 & $4.2-5.3$ & 324.86 & 5.93 & $11.5-13.7$ & 252.55 & 4.61 \\
\hline $6.3-8.7$ & 728.04 & 13.29 & $3.6-3.9$ & 575.06 & 10.50 & $5.3-6.9$ & 533.64 & 9.74 & $13.7-17.6$ & 479.4 & 8.75 \\
\hline $8.7-13.2$ & 1317.09 & 24.04 & $3.9-4.4$ & 1797.18 & 32.81 & $6.9-9.4$ & 2612.14 & 47.68 & $17.6-24.5$ & 764.28 & 13.95 \\
\hline $13.2-21.4$ & 2001.61 & 36.54 & $4.4-5.2$ & 1354.74 & 24.73 & $9.4-13.2$ & 1103.57 & 20.15 & $24.5-36.5$ & 3096.05 & 56.52 \\
\hline $21.4-36.2$ & 654.88 & 11.95 & $5.2-6.5$ & 379.99 & 6.94 & $13.2-19.1$ & 381.51 & 6.96 & $36.5-57.6$ & 576.31 & 10.52 \\
\hline $36.2-63.2$ & 144.01 & 2.63 & $6.5-8.5$ & 268.06 & 4.89 & $19.1-27.9$ & 54.97 & 1.00 & $57.6-94.5$ & 126.27 & 2.31 \\
\hline$>63.2$ & 0 & 0.00 & $>8.5$ & 0 & 0.00 & $>27.9$ & 0 & 0.00 & $>94.5$ & 0 & 0.00 \\
\hline
\end{tabular}

Table 4 Area distribution of EC and SAR within different classes in groundwater of Kerman plain

\begin{tabular}{|c|c|c|c|c|c|}
\hline \multicolumn{3}{|l|}{$\mathrm{EC}(\mu \mathrm{S} / \mathrm{cm})$} & \multicolumn{3}{|c|}{ SAR $\left(\text { meq } 1^{-1}\right)^{0.5}$} \\
\hline Class & Area $\left(\mathrm{km}^{2}\right)$ & Area $(\%)$ & Class & Area $\left(\mathrm{km}^{2}\right)$ & Area $(\%)$ \\
\hline $382-774$ & 46.06 & 0.84 & $0.6-1.9$ & 8.30 & 0.15 \\
\hline $774-1007$ & 117.12 & 2.14 & $1.9-2.5$ & 71.68 & 1.31 \\
\hline $1007-1145$ & 109.61 & 2.00 & $2.5-2.8$ & 66.25 & 1.21 \\
\hline $1145-1378$ & 214.23 & 3.91 & $2.8-3.1$ & 95.67 & 1.75 \\
\hline $1378-1769$ & 504.85 & 9.22 & $3.1-3.3$ & 72.25 & 1.32 \\
\hline $1769-2428$ & 1280.00 & 23.37 & $3.3-4.1$ & 346.18 & 6.32 \\
\hline $2428-3535$ & 2689.21 & 49.09 & $4.1-5.2$ & 528.47 & 9.65 \\
\hline $3535-5397$ & 397.28 & 7.25 & $5.2-7.8$ & 3741.44 & 68.30 \\
\hline $5397-8528$ & 119.70 & 2.19 & $7.8-13.1$ & 443.94 & 8.10 \\
\hline$>8528$ & 0 & 0.00 & $13.1-23.6$ & 103.88 & 1.90 \\
\hline
\end{tabular}

observed in class $5.2-7.8\left(\text { meq } 1^{-1}\right)^{0.5}$. In fact, a considerable percent of the aquifer exhibited salinity limitations with EC values more than $2250 \mu \mathrm{S} \mathrm{cm}^{-1}$ and little danger of developing harmful levels of sodium. Therefore, this part of groundwater cannot be used for irrigation of soils of restricted drainage. Even with adequate drainage, special management for salinity control including provision for high degree of adverse effects may be required and agricultural crops of very salt tolerance can be cultivated. Kotuby et al. (1997) concluded that EC levels over $2250 \mu \mathrm{S} \mathrm{cm}^{-1}$ can lead to yield reductions of about $50 \%$ for rice, tomato, peppers, spinach and corn.

As illustrated above, a new approach was offered for modeling the spatiotemporal changes of groundwater properties with time (year) based on the regression coefficient (RC). The value of $\mathrm{RC}$ obtained for each groundwater property represents the slope changes with time. Positive values indicate an increase in the amount of each groundwater variable over years and vice versa. Table 5 shows the average, minimum and maximum values of $\mathrm{RC}$
Table 5 Summary statistics of the regression coefficient (RC) for the groundwater properties in the study area

\begin{tabular}{|c|c|c|c|}
\hline Variable & Average & Minimum & Maximum \\
\hline $\mathrm{Na}^{+}\left(\right.$meq $1^{-1}$ year $\left.^{-1}\right)$ & 0.03 & -1.59 & 1.61 \\
\hline $\mathrm{Ca}^{+2}\left(\right.$ meq $^{-1}$ year $\left.^{-1}\right)$ & 0.15 & -0.34 & 1.49 \\
\hline $\mathrm{Mg}^{+2}\left(\right.$ meq $1^{-1}$ year $\left.^{-1}\right)$ & -0.11 & -1.47 & 0.73 \\
\hline Cations (meq $1^{-1}$ year $^{-1}$ ) & 0.15 & -2.04 & 3.02 \\
\hline $\mathrm{Cl}^{-}\left(\right.$meq $1^{-1}$ year $\left.^{-1}\right)$ & 0.18 & -1.07 & 3.00 \\
\hline $\mathrm{HCO}_{3}{ }^{-}\left(\right.$meq $1^{-1}$ year $\left.^{-1}\right)$ & 0.00 & -0.24 & 0.58 \\
\hline $\mathrm{SO}_{4}^{-2}\left(\right.$ meq $1^{-1}$ year $\left.^{-1}\right)$ & -0.10 & -3.05 & 1.51 \\
\hline Anions (meq $1^{-1}$ year $^{-1}$ ) & 0.09 & -1.98 & 3.07 \\
\hline $\mathrm{EC}\left(\mu \mathrm{S} \mathrm{cm} \mathrm{cm}^{-1}\right.$ year $\left.^{-1}\right)$ & 16.8 & -108.1 & 299.1 \\
\hline $\operatorname{SAR}\left[\left(\operatorname{meq~} 1^{-1}\right)^{0.5}\right.$ year $\left.^{-1}\right]$ & -0.01 & -0.73 & 0.58 \\
\hline
\end{tabular}

Negative value of RC for each groundwater property implies that the property over time (year) is gradually becoming smaller and vice versa

for each groundwater variable in the study Kerman plain. The result showed that $\mathrm{Na}^{+}, \mathrm{Ca}^{+2}, \mathrm{Cl}^{-}$, total cations, total anions and EC had on average positive values of RC. In 
fact, these groundwater variables have gradually increased during 1999-2010. Among the main soluble ions, $\mathrm{Cl}^{-}$ showed the highest increase with an average RC value of $0.18 \mathrm{meq}^{-1} \mathrm{y}^{-1}$. Also, the EC of groundwater showed an increasing trend with an average of $16.8 \mu \mathrm{S} \mathrm{cm}^{-1} \mathrm{y}^{-1}$. The value of $\mathrm{RC}$ for $\mathrm{HCO}_{3}{ }^{-}$was zero, indicating no changes through the studied years. In contrast, $\mathrm{Mg}^{+2}$ and $\mathrm{SO}_{4}^{-2}$ with respectively -0.11 and $-0.10 \mathrm{meq}^{-1} \mathrm{y}^{-1}$ and SAR with -0.01 (meq $\left.1^{-1}\right)^{0.5} \mathrm{y}^{-1}$ exhibited negative values of RC. However, these values of $\mathrm{RC}$ represent the average time changes for the whole aquifer, while ranged between negative and positive values.

\section{Varogram analysis}

Classical statistics are not necessarily suitable for analysis of variation patterns of every variable, because groundwater properties often exhibit spatial dependence. Also, each groundwater variable can be modeled as a function of time (year). Therefore, to determine the spatiotemporal behavior of the groundwater properties, the spatial dependency of regression coefficient (RC) for each property was modeled using analysis of semi-variance. By this way, both spatial and temporal variability of the groundwater variables were quantified. Table 6 presents the semi-variogram model parameters of the $\mathrm{RC}$ for different water quality variables as well as cross validation result in the study area obtaining for years 1999-2010. The result indicated that the best method for interpolation of $\mathrm{Na}^{+}, \mathrm{Mg}^{+2}, \mathrm{Cl}^{-}$, $\mathrm{HCO}_{3}{ }^{-}$and $\mathrm{SAR}$ was disjunctive Kriging, whereas for $\mathrm{Ca}^{+2}$, total cations, total anions and EC simple Kriging found to be the best method. In addition, the performance of ordinary Kriging resulted in a better interpolation for $\mathrm{SO}_{4}^{-2}$.

The variography analysis indicated that Exponential model for $\mathrm{Na}^{+}, \mathrm{Cl}^{-}, \mathrm{SO}_{4}^{-2}$, total cations and $\mathrm{SAR}$, the Gaussian model for $\mathrm{Ca}^{+2}$ and $\mathrm{Mg}^{+2}$, and the Spherical model for $\mathrm{HCO}_{3}{ }^{-}$, total anions and $\mathrm{EC}$ were the most satisfactory predictors. Nazarizadeh et al. (2006) found that the variograms of $\mathrm{EC}, \mathrm{Cl}^{-}$and $\mathrm{SO}_{4}^{-2}$ best fit with the spherical model. In another research, Maghami et al. (2011) performed groundwater quality zonation using 27 observed wells in Abadeh Township, with an unconfined aquifer. Their result showed that the Kriging method with an exponential semi-variogram was the best method for interpolating the quality of drinking water.

Our result also showed that the nugget ranged from 0 to 0.47 for the main soluble ions, while it was found to be 1513 and 0.67 for EC and SAR, respectively. The nugget is mainly caused by small scale variations, or sometimes just by measurement errors. With the nugget effect, the Kriging weights become similar and the variance of estimation error increases. If there is no nugget effect, the average standard deviation generally decreases with the increase of the number of observation wells (Yang et al. 2008).

Sill is a constant value for bounded variograms or an asymptotic value for unbounded variograms (Webster and Oliver 2001). With the same number of observation wells, the average standard deviation is large for large sill value. Therefore, for a given maximum tolerable average standard deviation, more observation wells are required for the case with large sill values (Yang et al. 2008). Our result indicated that the minimum and maximum values of sill obtained for $\mathrm{Ca}^{+2}$ and $\mathrm{Na}^{+}$with the amounts of 0.12 and 1.34, respectively. Sill values for EC and SAR were 4096 and 1.17 , respectively.

The nugget-to-sill ratio, which is also known as the relative nugget variance, can determine the grade of the spatial dependence of any variable. Spatial dependence of groundwater variables was classified according to nuggetto-sill ratio (\%), with a ratio of $<25 \%$ indicating a strong spatial dependence, a ratio of $25-75 \%$ indicating moderate spatial dependence and a ratio of $>75 \%$ indicating a weak spatial dependence (Kravchenko 2003; Rossi et al. 2009;

Table 6 Semi-variogram model parameters of the regression coefficient (RC) for different water quality properties in the study area

\begin{tabular}{|c|c|c|c|c|c|c|c|c|c|c|}
\hline Variable & $\begin{array}{l}\text { Geostatistical } \\
\text { algorithm }\end{array}$ & Model & $\begin{array}{l}\text { Nugget } \\
\text { (C0) }\end{array}$ & $\begin{array}{l}\text { Partial sill } \\
\text { (C) }\end{array}$ & $\begin{array}{l}\text { Sill } \\
(\mathrm{C} 0+\mathrm{C})\end{array}$ & $\begin{array}{l}\text { Range } \\
(\mathrm{m})\end{array}$ & $\begin{array}{l}\text { Spatial } \\
\text { dependency }\end{array}$ & RMSE & MAE & MBE \\
\hline $\mathrm{Na}^{+}$ & Disjunctive Kriging & Exponential & 0.21 & 1.13 & 1.34 & 7970 & Strong & 0.51 & 0.34 & 0.01 \\
\hline $\mathrm{Ca}^{+2}$ & Simple Kriging & Gaussian & 0.05 & 0.07 & 0.12 & 15,038 & Moderate & 0.31 & 0.21 & -0.01 \\
\hline $\mathrm{Mg}^{+2}$ & Disjunctive Kriging & Gaussian & 0.47 & 0.54 & 1.01 & 9096 & Moderate & 0.33 & 0.23 & 0.01 \\
\hline Cations & Simple Kriging & Exponential & 0.04 & 0.65 & 0.69 & 12,009 & Strong & 0.69 & 0.44 & 0.02 \\
\hline $\mathrm{Cl}^{-}$ & Disjunctive Kriging & Exponential & 0.08 & 0.46 & 0.54 & 31,273 & Strong & 0.50 & 0.3 & 0.007 \\
\hline $\mathrm{HCO}_{3}{ }^{-}$ & Disjunctive Kriging & Spherical & 0.43 & 0.79 & 1.22 & 23,116 & Moderate & 0.14 & 0.09 & 0.007 \\
\hline $\mathrm{SO}_{4}^{-2}$ & Ordinary Kriging & Exponential & 0 & 0.65 & 0.65 & 12,496 & Strong & 0.71 & 0.43 & 0.01 \\
\hline Anions & Simple Kriging & Spherical & 0.07 & 0.69 & 0.76 & 10,733 & Strong & 0.72 & 0.48 & 0.02 \\
\hline $\mathrm{EC}$ & Simple Kriging & Spherical & 1513 & 2583 & 4096 & 14,225 & Moderate & 56.23 & 37.72 & 0.45 \\
\hline SAR & Disjunctive Kriging & Exponential & 0.67 & 0.50 & 1.17 & 65,703 & Moderate & 0.22 & 0.15 & 0.0008 \\
\hline
\end{tabular}


Wang et al. 2009; Arslan 2012). Findings for nugget-to-sill ratios in the present study indicated the groundwater variables to have moderate to strong spatial structure. Overall, small nugget-to-sill ratios and large spatial correlation ranges usually indicate that high accuracy can be achieved when mapping a variable (Isaaks and Srivastava 1989).

The effective range is the distance beyond which the variogram value remains essentially constant. The larger the range is, the stronger the spatial correlation is (Webster and Oliver 2001). According to Table 6, the minimum and maximum ranges were found for $\mathrm{Na}^{+}$and SAR with the values of 7970 and $65,703 \mathrm{~m}$, respectively. Zehtabian et al. (2010) in modeling of Garmsar groundwater quality reported that the best fit model for total cations, total anions and $\mathrm{SO}_{4}^{-2}$ was similarly spherical with a range of $51,100 \mathrm{~m}$, whereas a linear model with a range of $20,896 \mathrm{~m}$ found to be the best for $\mathrm{HCO}_{3}{ }^{-}$. The range obtained by Nazarizadeh et al. (2006) in Balaroud groundwater for $\mathrm{EC}, \mathrm{Cl}^{-}$and $\mathrm{SO}_{4}^{-2}$ was $61,700,50,800$ and $102,100 \mathrm{~m}$, respectively.

The cross-validation statistics given in Table 6 show how well groundwater variables can be estimated by application of the selected Kriging interpolation models. Smaller values of RMSE, MAE and MBE indicate that the estimated values are closer to the observed values. The result showed that for the main soluble ions the values of RMSE and MAE ranged from 0.14 to 0.72 and from 0.09 to 0.48 , respectively. The values of these two parameters obtained for the groundwater EC were respectively 56.23 and 37.72. Moreover, cross-validation result showed that MBE values to be close to 0 , i.e. between -0.01 and 0.02 for the main soluble ions and 0.45 for EC, indicating an accuracy of predictions (Sun et al. 2009).

\section{Spatial mapping}

Once cross-validated, the parameters of the semi-variogram models were used in the construction of spatiotemporal groundwater quality maps for irrigation by the selected geostatistical methods. In other words, the prepared maps show the spatial variability of the RC parameter, which by itself represents the temporal changes of each groundwater property at every point during 1999-2010. In this regard, three groups of maps including (1) soluble cations, (2) soluble anions and (3) EC and SAR were generated (Figs. 3, 4, 5).

According to Fig. 3a, most of the study area allocated to class 0.01-0.05 meq $1^{-1}$ year $^{-1}$. Instead, spatial changes of $\mathrm{RC}$ parameter for $\mathrm{Na}^{+}$in the north central and western parts of the plains, especially beneath the city had no clear pattern. According to Table 5, the average RC for soluble $\mathrm{Na}^{+}$was $0.03 \mathrm{meq}^{-1} \mathrm{lear}^{-1}$, varying between -1.59 and $1.61 \mathrm{meq}^{-1}$ year $^{-1}$. Spatiotemporal variability map of soluble $\mathrm{Ca}^{+2}$ is shown in Fig. 3b. The dominant class of RC parameter was $0.12-0.27$ meq $1^{-1}$ year $^{-1}$, indicating an increasing trend in the concentration of $\mathrm{Ca}^{+2}$ during 1999-2010 in most area of the aquifer. However, some negative values of RC parameter were observed in the central part of the plain, where the city has been developed. The value of $\mathrm{RC}$ for $\mathrm{Ca}^{+2}$ varied from -0.34 to 1.49 with an average of 0.15 meq $^{-1}$ year $^{-1}$. Spatial changes of RC parameter for groundwater $\mathrm{Mg}^{+2}$ (Fig. 3c) indicated that most areas of the aquifer are placed in class -0.15 to -0.08 meq $^{-1}$ year $^{-1}$. Unlike $\mathrm{Na}^{+}$and $\mathrm{Ca}^{+2}$, the soluble $\mathrm{Mg}^{+2}$ exhibited a decreasing trend over the years with an average RC value of -0.11 ranging from -1.47 to $0.73 \mathrm{meq}^{-1}$ year $^{-1}$ (Table 5). Most irregularities in the spatial changes of $\mathrm{Mg}^{+2}$ were observed in the central and western parts of the aquifer. The prepared map of spatial changes of RC for total cations (Fig. 3d) was relatively similar to that one obtained for $\mathrm{Ca}^{+2}$ with an average of 0.15 meq $^{-1}$ year $^{-1}$. The most abundant values of $\mathrm{RC}$ parameter were classified in the range of 0.05-0.35 meq $1^{-1}$ year $^{-1}$. In general, the north central and western parts of Kerman aquifer showed different patterns of spatiotemporal variability from the other areas.

The concentration of soluble $\mathrm{Cl}^{-}$showed the highest reductions in central as well as western parts of the study area (Fig. 4a). According to Table 5, the average value of $\mathrm{RC}$ was $0.18 \mathrm{meq}^{-1}$ year $^{-1}$, ranging from -1.07 to 3.0 meq $1^{-1}$ year $^{-1}$. In most area of the Kerman groundwater, the average value of $\mathrm{RC}$ obtained for $\mathrm{HCO}_{3}{ }^{-}$was equal to or less than zero, indicating that the concentration of this anion had no increasing trend from 1999 to 2010 (Fig. 4b). However, beneath the city region, positive values of RC parameter were observed. A plausible reason for increasing the concentration of $\mathrm{HCO}^{-}$in this area can be due to organic substance degradation in domestic waste water (Hassanzadeh et al. 2011). In another study, geogenic (Fe-oxides, calcareous rocks with phosphorite intercalations, ophiolite fragments within deltaic deposits) and anthropogenic contamination sources (intensive agricultural and farming practices) were found to control the spatial distribution of some elements in stream sediments of Arta plain (Papadopoulou-Vrynioti et al. 2013). Our result showed that in the residential areas, the value of RC parameter for $\mathrm{SO}_{4}^{-2}$ was negative (Fig. 4c). The average

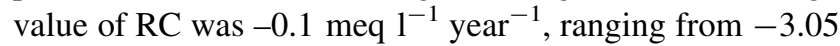
to $1.51 \mathrm{meq}^{-1}$ year $^{-1}$. Anyway, more irregularities in spatiotemporal patterns of $\mathrm{SO}_{4}^{-2}$ than in the other ions were observed. The result also implied that the RC parameter for total anions ranged from -1.98 to $3.07 \mathrm{meq}^{-1}$ year $^{-1}$ with an average value of 0.09 meq $1^{-1}$ year $^{-1}$. Most of the area allocated to class -0.07 to 0.11 (Fig. 4d). Meanwhile, some negative and positive values of RC parameter were observed in the north central and western parts of the plain. 

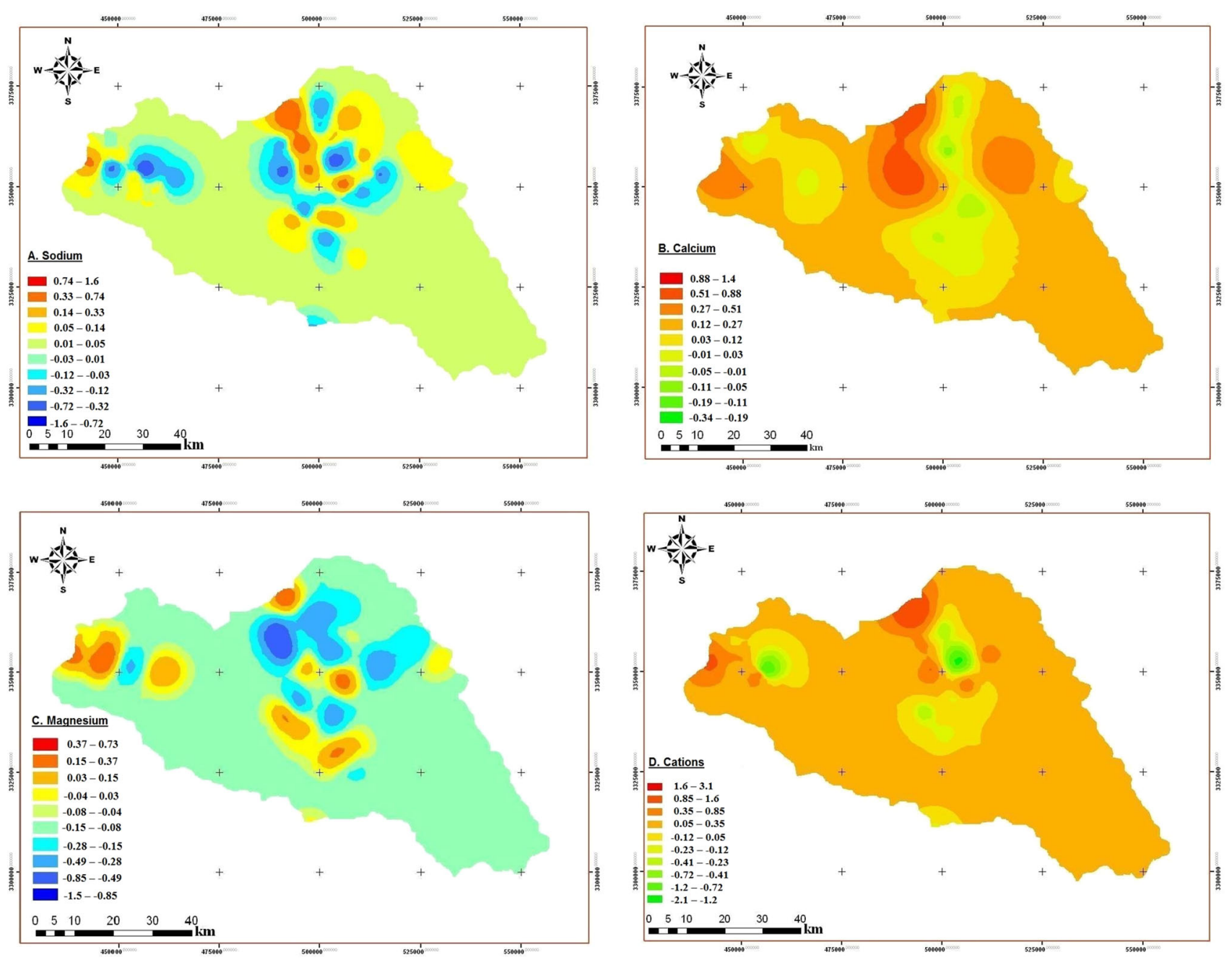

Fig. 3 Spatiotemporal mapping of RC parameter for soluble cations in Kerman aquifer including sodium (a), calcium (b), Magnesium (c) and total cations (d)

Figure 5a shows the spatiotemporal variability of EC for irrigation in the aquifer. The dominant class of $\mathrm{RC}$ parameter for EC was $8.6-18.9 \mu \mathrm{S} \mathrm{cm}^{-1} \mathrm{year}^{-1}$. It is obvious that some parts in north central and western parts of the plain exhibited negative values of RC. Based on Table 5, the range of RC parameter for groundwater EC varied from -108.1 to $299.1 \mu \mathrm{S} \mathrm{cm} \mathrm{cm}^{-1}$ year $^{-1}$ with an average value of $16.8 \mu \mathrm{S} \mathrm{cm}^{-1}$ year $^{-1}$. The spatiotemporal variability of groundwater SAR differed from the soluble ions, so that toward the western parts of the plain, the negativity of RC parameter intensified. This trend can be ascribed to the reduction of soluble $\mathrm{Na}^{+}$as well as increases in $\mathrm{Ca}^{+2}$ and $\mathrm{Mg}^{+2}$ in the west part (Fig. 3). The value of $\mathrm{RC}$ parameter for groundwater SAR ranged from -0.73 to $0.58\left(\text { meq }^{-1}\right)^{0.5}$ year $^{-1}$, with an average of 0.01 (meq 1 $\left.^{-1}\right)^{0.5}$ year $^{-1}$.

Comparison of the main soluble ions indicated that during 1999-2010, the concentration of $\mathrm{HCO}^{-}$has been increased beneath the Kerman city, whereas the reverse manner was found for $\mathrm{Ca}^{+2}$ and $\mathrm{SO}_{4}^{-2}$. The increase of $\mathrm{HCO}^{-}$may be due to human activities and the consequent groundwater enrichment by domestic waste water. The reverse manner for $\mathrm{Ca}^{+2}$ and $\mathrm{SO}_{4}^{-2}$ is partly as a result of raised groundwater level and the entrance of water and waste water with relatively low amounts of theses ions into the ground water (Hasanpour et al. 2011). The spatial distribution of water $\mathrm{Cl}^{-}$concentrations and EC values for agricultural use in the Arta plain showed that sea water intrusion was responsible for its elevated salt contents in the coastal area (Papadopoulou-Vrynioti et al. 2014). Our result indicated that in the north central part of the plain where the urban areas have been developed, the most irregularity in the spatiotemporal changes of the groundwater properties was found. This can be attributed to the groundwater enrichment by domestic waste water due to human activities combined with the weathering of evaporates such as halite and gypsum. 

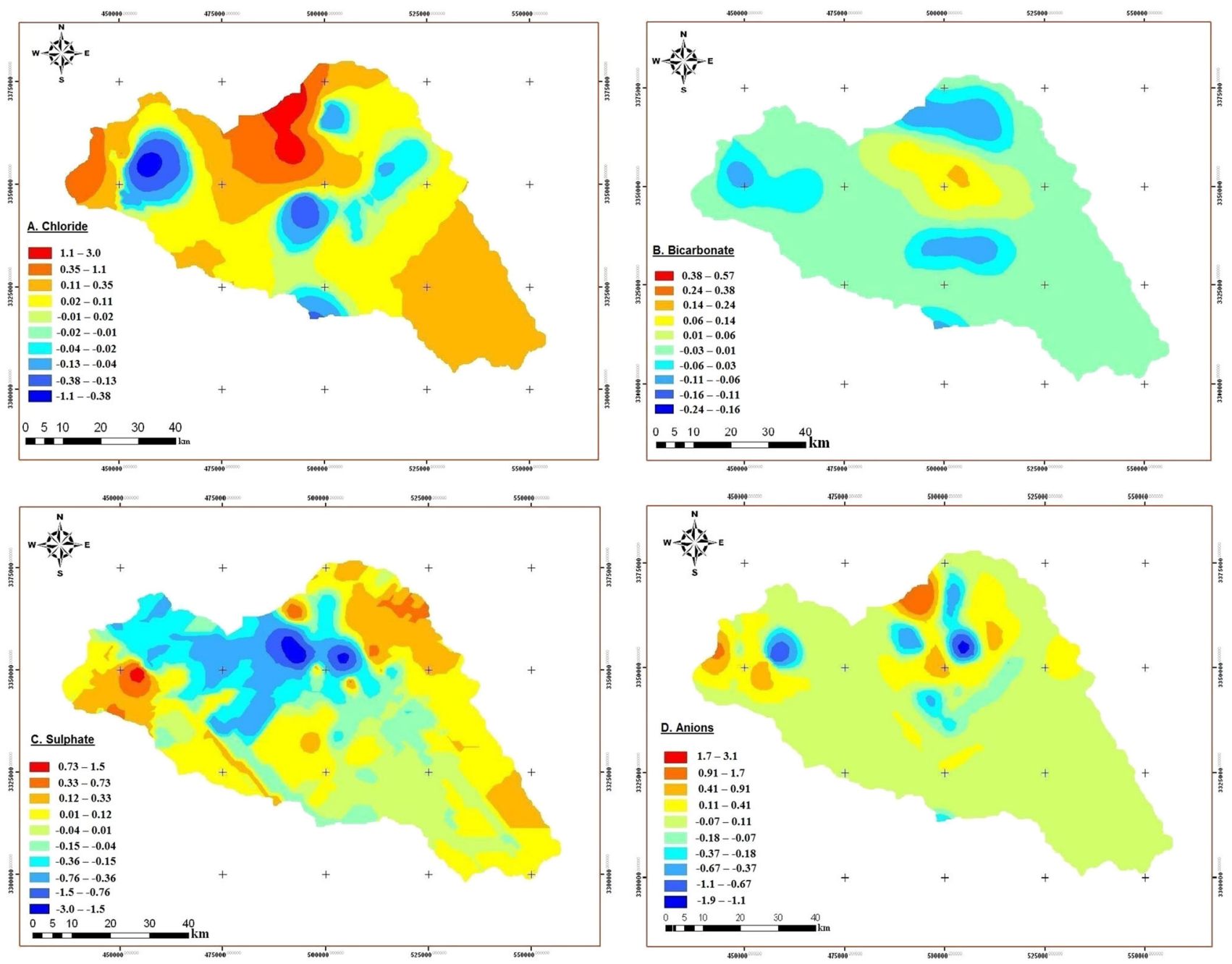

Fig. 4 Spatiotemporal mapping of RC parameter for soluble anions in Kerman aquifer including chloride (a), bicarbonate (b), sulfate (c) and total anions (d)

Based on correlation coefficients obtained among the RC parameters, the similarities between the sources of ions can be distinguished. Table 7 presents a simple correlation among the $\mathrm{RC}$ values for the groundwater irrigation qualities. The RC parameter for groundwater EC had the highest correlation coefficients with $\mathrm{Cl}^{-}(\mathrm{r}=0.72 * *)$ and $\mathrm{Na}^{+}\left(\mathrm{r}=0.70^{* *}\right)$, afterward with $\mathrm{Ca}^{+2}\left(\mathrm{r}=0.52^{* *}\right)$, $\mathrm{Mg}^{+2}(\mathrm{r}=0.47 * *)$ and $\mathrm{SO}_{4}^{-2}\left(\mathrm{r}=0.38^{* *}\right)$. Reversely, it showed no significant relationship with $\mathrm{HCO}^{-}$. This can be explained partly by weathering of evaporate minerals (halite and gypsum) in the Kerman Plain (Rezaei 2013). In addition, the groundwater RC parameter for SAR showed significant relationships with $\mathrm{Na}^{+}\left(\mathrm{r}=0.74^{* *}\right)$ and $\mathrm{Cl}^{-}$ $\left(\mathrm{r}=0.33^{* *}\right)$, whereas no significant correlation was found with the other soluble ions. This finding indicated that the spatiotemporal changes of groundwater salinity (EC) and sodicity (SAR) of Kerman plain during 1999-2010 have been mainly controlled by soluble $\mathrm{Na}^{+}$and $\mathrm{Cl}^{-}$.
Meanwhile, there was a positive relationship between the RC parameters of soluble $\mathrm{Na}^{+}$and $\mathrm{Cl}^{-}\left(\mathrm{r}=0.50^{* *}\right)$.

\section{Conclusion}

Spatiotemporal mapping of Kerman groundwater variables during 1999-2010 was performed using Kriging technique combined with a linear regression approach. The result showed that among the main soluble ions, $\mathrm{Na}^{+}$and $\mathrm{Cl}^{-}$had the highest concentrations in the groundwater. Except $\mathrm{Ca}^{+2}$, the average concentration of all the other soluble ions and also EC were higher than the maximum permissible levels for drinking, however, $\mathrm{Na}^{+}, \mathrm{SO}_{4}^{-2}$ and $\mathrm{EC}$ showed no limitation for agricultural water usage. Based on the proposed $\mathrm{RC}$ parameter, soluble $\mathrm{Na}^{+}, \mathrm{Ca}^{+2}, \mathrm{Cl}^{-}$, total cations, total anions and EC have gradually increased during 1999-2010. Among the main soluble ions, $\mathrm{Cl}^{-}$with 
Fig. 5 Spatiotemporal mapping of RC parameter for EC (a) and SAR (b) in Kerman plain aquifer
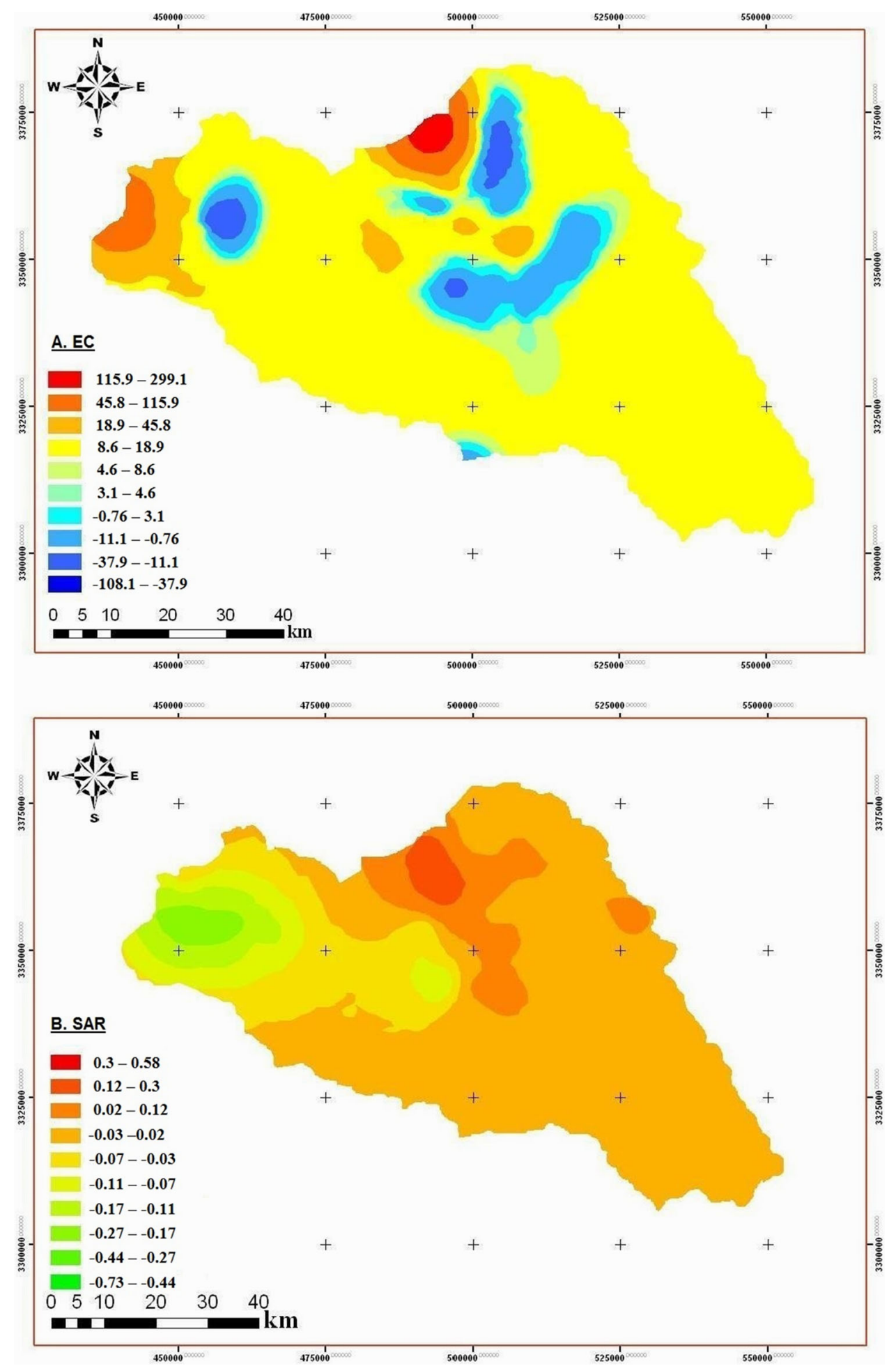

$0.18 \mathrm{meq}^{-1}$ year $^{-1}$ showed on average the highest value of RC. Also, the groundwater EC showed an increasing trend with an average value of $16.8 \mu \mathrm{S} \mathrm{cm}^{-1}$ year $^{-1}$. In contrast, $\mathrm{Mg}^{+2}, \mathrm{SO}_{4}^{-2}$ and $\mathrm{SAR}$ exhibited negative values of $\mathrm{RC}$. The value of $\mathrm{RC}$ for $\mathrm{HCO}_{3}{ }^{-}$was zero, indicating no changes through the studied years. The geostatistics result showed that the best method for interpolation of $\mathrm{Na}^{+}$, $\mathrm{Mg}^{+2}, \mathrm{Cl}^{-}, \mathrm{HCO}_{3}{ }^{-}$and SAR was disjunctive Kriging, whereas for $\mathrm{Ca}^{+2}$, total cations, total anions and EC, simple Kriging found to be the best method. In addition, the performance of ordinary Kriging resulted in a better interpolation for $\mathrm{SO}_{4}^{-2}$. The analysis of semi-variogram indicated 
Table 7 Simple correlation among regression coefficients (RC) for the groundwater properties of Kerman plain aquifer

\begin{tabular}{|c|c|c|c|c|c|c|c|c|c|c|}
\hline Variable & $\mathrm{Na}^{+}$ & $\mathrm{Ca}^{+2}$ & $\mathrm{Mg}^{+2}$ & Cations & $\mathrm{Cl}^{-}$ & $\mathrm{HCO}_{3}{ }^{-}$ & $\mathrm{SO}_{4}^{-2}$ & Anions & EC & $\overline{\text { SAR }}$ \\
\hline $\mathrm{Na}^{+}$ & 1 & & & & & & & & & \\
\hline $\mathrm{Ca}^{+2}$ & $0.098 \mathrm{~ns}$ & 1 & & & & & & & & \\
\hline $\mathrm{Mg}^{+2}$ & $0.22 \mathrm{~ns}$ & $-0.11 \mathrm{~ns}$ & 1 & & & & & & & \\
\hline Cations & $0.80 * *$ & $0.51 * *$ & $0.40 * *$ & 1 & & & & & & \\
\hline $\mathrm{Cl}^{-}$ & $0.50 * *$ & $0.57 * *$ & $0.04 \mathrm{~ns}$ & $0.66 * *$ & 1 & & & & & \\
\hline $\mathrm{HCO}_{3}{ }^{-}$ & $-0.16 \mathrm{~ns}$ & $0.03 \mathrm{~ns}$ & $-0.40 * *$ & $-0.22 \mathrm{~ns}$ & $0.07 \mathrm{~ns}$ & 1 & & & & \\
\hline $\mathrm{SO}_{4}^{-2}$ & $0.43 * *$ & $-0.005 \mathrm{~ns}$ & $0.61 * *$ & $0.48 * *$ & $-0.27 *$ & $-0.57 * *$ & 1 & & & \\
\hline Anions & $0.80 * *$ & $0.49 * *$ & $0.51 * *$ & $0.95 * *$ & $0.63 * *$ & $-0.27 *$ & $0.56 * *$ & 1 & & \\
\hline $\mathrm{EC}$ & $0.70 * *$ & $0.52 * *$ & $0.47 * *$ & $0.89 * *$ & $0.72 * *$ & $-0.18 \mathrm{~ns}$ & $0.38 * *$ & $0.92 * *$ & 1 & \\
\hline SAR & $0.74 * *$ & $-0.096 \mathrm{~ns}$ & $-0.22 \mathrm{~ns}$ & $0.36 * *$ & $0.33 *$ & $0.098 \mathrm{~ns}$ & $0.055 \mathrm{~ns}$ & $0.35 * *$ & $0.27 *$ & 1 \\
\hline
\end{tabular}

$n s$ not significant

$* \mathrm{p}<0.05$

$* * \mathrm{p}<0.01$

that Exponential model for $\mathrm{Na}^{+}, \mathrm{Cl}^{-}, \mathrm{SO}_{4}^{-2}$, total cations and SAR, the Gaussian model for $\mathrm{Ca}^{+2}$ and $\mathrm{Mg}^{+2}$, and the Spherical model for $\mathrm{HCO}_{3}{ }^{-}$, total anions and $\mathrm{EC}$ were the most satisfactory predictors. Nugget-to-sill ratios in the present study indicated the groundwater properties to have moderate to strong spatial structure. The minimum and maximum ranges were found for $\mathrm{Na}^{+}$and SAR with the values of 7970 and $65,703 \mathrm{~m}$, respectively. Comparison of the main soluble ions showed that during 1999 to 2010 , the concentration of $\mathrm{HCO}^{-}$has been increased beneath the Kerman city, whereas the reverse manner was found for $\mathrm{Ca}^{+2}$ and $\mathrm{SO}_{4}^{-2}$. The RC parameter for groundwater EC and SAR had the highest correlation coefficients with $\mathrm{Na}^{+}$ and $\mathrm{Cl}^{-}$. This finding indicated that the spatiotemporal changes of groundwater salinity (EC) and sodicity (SAR) of Kerman plain during 1999-2010 have been manly controlled by soluble $\mathrm{Na}^{+}$and $\mathrm{Cl}^{-}$.

\section{References}

Aminizadeh M, Lashkaripour Gh, Ghaoori M, Hafezi N (2012) Investigation of bed rock condition of Kerman plain based on sedimentary basin model. Irrig Water Eng 2(7):70-82 (in Persian)

Arslan H (2012) Spatial and temporal mapping of groundwater salinity using ordinary Kriging and indicator Kriging: The case of Bafra Plain, Turkey. Agri Water Manage 113:57-63

Asadi R, Kuhi N, Yazdanpanah N (2012) Applicability of micro irrigation system on cotton yield and water use efficiency. $\mathrm{J}$ food Agri Envir 10(1):302-306

Baalousha H (2010) Assessment of a groundwater quality monitoring network using vulnerability mapping and geostatistics: a case study from Heretaunga Plains, New Zealand. Agri Water Manage 97:240-246

Dash JP, Sarangi A, Singh DK (2010) Spatial variability of groundwater depth and quality parameters in the National Capital Territory of Delhi. Envir Manage 45:640-650
Delgado C, Pacheco J, Cabrea A, Baltlori E, Orellana R, Baustista F (2010) Quality of groundwater for irrigation in tropical karst environment; the case of Yucatan, Mexico. Agri Water Manage 97:1423-1433

Demir Y, Ersahin S, Guler M, Cemek B, Gunal H, Arslan H (2009) Spatial variability of depth and salinity of groundwater under irrigated ustifluvents in the Middle Black Sea Region of Turkey. Envir Monitor Assess 158:279-294

Environmental Protection Organization of Iran (2001) Executive Law, C: No. 104, 134. The Third Development Program. Green Circe Press (in Persian)

ESRI (2008) Using ArcGIS geostatistical analyst. Environmental Systems Research Institute, Redlands (300 pp)

Gaus I, Kinniburgh DG, Talbot JC, Webster R (2003) Geostatistical analysis of arsenic concentration in groundwater in Bangladesh using disjunctive Kriging. Envir Geol 44:939-948

Ghosh AK, Sarkar D, Dutta D, Bhattacharyya P (2004) Spatial variability and concentration of arsenic in the groundwater of a region in Nadia district, West Bengal, India. Archives Agron Soil Sci 50(4-5):521-527. doi:10.1080/0365034042000220757

Guo O, Wang Y, Gao X, Ma T (2007) A new model (DRARCH) for assessing groundwater vulnerability to arsenic contamination at basin scale: a case study in Taiyuanbasin, northern China. Envir Geol 52(5):923-932

Hasanpour N, Abbasnezhad A, Dadollahi H, Ghasemi Pourafshar Y (2011) Effect of water level rising on the aquifer quality of Kerman city. In: The 5th National Conference and Exhibition on Environmental Engineering. Tehran, Iran (in Persian)

Hassanzadeh R, Abbasnejad A, Hamzeh MA (2011) Assessment of groundwater pollution in Kerman urban areas. J Envir Stud 36(56):31-33

Holtz GK (2009) Seasonal variation in groundwater levels and quality under intensively drained and grazed pastures in the Montagu catchment, NW Tasmania. Agri Water Manage 96:255-266

Isaaks EH, Srivastava RM (1989) An introduction to applied geostatistics. Oxford University Press, New York

Kotuby J, Koenig R, Kitchen B (1997) Salinity and plant tolerance. Utah State University Extension, AG-SO-03, Utah

Kravchenko AN (2003) Influence of spatial structure on accuracy of interpolation methods. Soil Sci Soc Am J 67:1564-1571

Kuisi MA, Al-Qinna M, Margani A, Aljazzar T (2009) Spatial assessment of salinity and nitrate pollution in Amman-Zarqa Basin: a case study. J Envir Earth Sci 59:117-129 
Kumar V (2007) Optimal contour mapping of groundwater levels using universal Kriging, a case study. Hydro Sci J 52(5):1039-1049

Li J, Heap AD (2008) A review of spatial interpolation methods for environmental scientists. Geoscience publication, Australia

Maghami Y, Ghazavi R, Vali AA, Sharafi S (2011) Evaluation of spatial interpolation methods for water quality zoning using GIS Case study, Abadeh Township. Geog Envir Plann J 42(2):171-182 (in Persian)

Mendes MP, Ribeiro L (2010) Nitrate probability mapping in the northern aquifer alluvial system of the river Tagus (Portugal) using Disjunctive Kriging. Sci Total Envir 408:1021-1034

Moosavi AA, Sepaskhah AR (2012) Spatial variability of physicochemical properties and hydraulic characteristics of a gravelly calcareous soil. Archives Agron Soil Sci 58(6):631-656. doi:10. 1080/03650340.2010.533659

Mousavifard SM, Momtaz H, Sepehr E, Davatgar N, Rasouli Sadaghiani MH (2013) Determining and mapping some soil physico-chemical properties using geostatistical and GIS techniques in the Naqade region, Iran. Archives Agron Soil Sci 59(11):1573-1589. doi:10.1080/03650340.2012.740556

Nas B, Berktay A (2010) Groundwater quality mapping in urban groundwater using GIS. Envir Monitor Assess 160(1-4):215-227

Nazarizadeh F, Ershadian N, Zandevakili K (2006) Spatial variation of groundwater quality of Balaroud plain, Khuzestan Province. In: First Regional Conference on Optimum Utilization of Water Resources in the Karun and Zayanderud River Basins, Shahrekord University, pp 1236-1240 (in Persian)

Neshat A, Pradhan B, Dadras M (2014) Groundwater vulnerability assessment using an improved DRASTIC method in GIS. Reso Cons Recycl 86:74-86

Nourzadeh M, Mahdian MH, Malakouti MJ, Khavazi K (2012) Investigation and prediction spatial variability in chemical properties of agricultural soil using geostatistics. Archives Agron Soil Sci 58(5):461-475. doi:10.1080/03650340.2010. 532124

Papadopoulou-Vrynioti K, Alexakis D, Bathrellos GD, Skilodimou HD, Vryniotis D, Vassiliades E, Gamvroula D (2013) Distribution of trace elements in stream sediments of Arta plain (western Hellas): the influence of geomorphological parameters. J Geoch Expl 134:17-26. doi:10.1016/j.gexplo.2013.07.007

Papadopoulou-Vrynioti K, Alexakis D, Bathrellos GD, Skilodimou HD, Vryniotis D, Vassiliades E (2014) Environmental research and evaluation of agricultural soil of the Arta plain, western Hellas. J Geoch Expl 136:84-92. doi:10.1016/j.gexplo.2013.10. 007

Park SJ, Vlek PLG (2002) Environmental correlation of three dimensional soil spatial variability, a comparison of three adaptive techniques. Geoderma 10:117-140

Pazand K, Javanshir AR (2014) Geochemistry and water quality assessment of groundwater around Mohammadabad area, Bam district, SE Iran. Water Qual Expo Health 6:225-231. doi:10. 1007/s12403-014-0131-9
Rezaei M (2013) The chemical evolution of groundwater in the Kerman plain aquifer, Iran. Int J Water 7(1):29-43

Rossi J, Govaerts A, Vos BD, Verbist B, Vervoort A, Poesen J, Muys B, Deckers J (2009) Spatial structures of soil organic carbon in tropical forests, a case study of Southeastern Tanzania. Catena 77:19-27

Sun Y, Kang S, Li F (2009) Comparison of interpolation methods for depth to groundwater and its temporal and spatial variations in the Minqin oasis of northwest China. Envir Model Soft 24:1163-1170

The Planning and Management Organization of Kerman Province (2011) Statistical yearbook of Kerman province, Iran. No. 581 (in Persian)

Theodossiou N, Latinopoulos P (2007) Evaluation and optimisation of groundwater observation networks using the Kriging methodology. Envir Model Soft 21(7):991-1000

United States Environmental Protection Agency (2012) Edition of the drinking water standards and health advisories, Washington, DC. USA, pp 12

Wang Y, Zhang X, Huang C (2009) Spatial variability of soil total nitrogen and soil total phosphorus under different land uses in a small watershed on the Loess Plateau, China. Geoderma 150:141-149

Webster R (1997) Regression and functional relations. Eur J Soil Sci 48:557-566. doi:10.1111/j.1365-2389.1997.tb00222.x

Webster R, Oliver MA (2001) Geostatistics for environmental scientists. Wiley, New York

Yang FG, Cao SY, Liu XN, Yang KJ (2008) Design of groundwater level monitoring network with ordinary Kriging. J Hydrody 20(3):339-346

Yazdanpanah N, Mahmoodabadi M (2013) Reclamation of calcareous saline-sodic soil using different amendments: time changes of soluble cations in leachate. Arab J Geosci 6:2519-2528. doi:10. 1007/s12517-011-0505-2

Yazdanpanah N, Pazira E, Neshat A, Naghavi H, Moezi AA, Mahmoodabadi M (2011) Effect of some amendments on leachate properties of a calcareous saline-sodic soil. Int Agroph 25(3):307-310

Yazdanpanah N, Pazira E, Neshat A, Mahmoodabadi M, Rodríguez Sinobas L (2013) Reclamation of calcareous saline sodic soil with different amendments (II): impact on nitrogen, phosphorous and potassium redistribution and on microbial respiration. Agri Water Manage 120:39-45. doi:10.1016/j.agwat.2012.08.017

Yimit H, Eziz M, Mamat M, Tohti G (2011) Variations in groundwater levels and salinity in the Ili River Irrigation Area, Xinjiang, Northwest China: a geostatistical approach. Int J Sustain Dev World Ecol 18(1):55-64

Zehtabian Gh, Janfaza E, Mohammad Asgari H, Nematollahi MJ (2010) Modeling of ground water spatial distribution for some chemical properties (case study in Garmsar watershed). Iranian J Range Desert Res 17(1):61-73 (in Persian) 